Plankton Benthos Res 4(4): 129-134, 2009

\title{
Co-occurrence of DNA- and RNA-viruses infecting the bloom-forming dinoflagellate, Heterocapsa circularisquama, on the Japan coast
}

\author{
Yuji Tomaru*, Hiroyuki Mizumoto ${ }^{\dagger}$, Yoshitake TaKaO ${ }^{\ddagger} \&$ KeIzo NAgasaki \\ Harmful Algal Bloom Division, National Research Institute of Fisheries and Environment of Inland Sea, Fisheries Research \\ Agency, 2-17-5 Maruishi, Hatsukaichi, Hiroshima 739-0452, Japan
}

Received 23 March 2009; Accepted 24 June 2009

\begin{abstract}
In western Japan, Heterocapsa circularisquama blooms occur almost every year. Two distinct viruses infectious to $H$. circularisquama, a large double-stranded DNA (dsDNA) virus, 'HcV', and a small single-stranded RNA (ssRNA) virus, 'HcRNAV', were found and characterized. Here we report the co-occurrence of the two viruses in Hiroshima Bay, Japan, during 2006. Viruses isolated using H. circularisquama strains HU9433-P and MZ2 (the hosts) were large dsDNA viruses (ca. $0.2 \mu \mathrm{m}$ in diameter) that accumulated in the host cytoplasm. Pulsed-field gel electrophoresis analysis showed their genome sizes were ca. $388 \mathrm{kbp}$, comparable to the previously reported HcV strain. Small ssRNA viruses were also isolated (using the host strain HCLG-1) at ca. $30 \mathrm{~nm}$ in diameter and formed crystalline arrays and/or were randomly accumulated in the host cytoplasm, and their partial genome sequences were highly similar to a previously reported HcRNAV strain. This is the first report of the co-occurrence of HcV and HcRNAV in natural water and their successful isolation. The data suggest the two distinct viruses may cooperatively affect the dynamics of H. circularisquama blooms.
\end{abstract}

Key words: Algal virus, dinoflagellate, HcRNAV, HcV, Heterocapsa circularisquama

\section{Introduction}

Heterocapsa circularisquama Horiguchi is a bloomforming small thecate dinoflagellate that kills bivalves (Horiguchi 1995); and is one of the most noxious marine microorganisms causing harmful algal blooms (HABs). Since the first occurrence of this alga was recorded in Uranouchi Inlet, Kochi Prefecture, Japan, its distribution area has expanded rapidly in embayments throughout central and western Japan (Matsuyama 2003).

Two different viruses infecting $H$. circularisquama have been isolated from western Japan. A large icosahedral double-stranded DNA (dsDNA) virus, H. circularisquama virus $(\mathrm{HcV})$, was isolated from Tanabe Bay, Wakayama Prefecture in 1999 (Tarutani et al. 2001). The other, a small single-stranded RNA (ssRNA) virus, $H$. circularisquama RNA virus (HcRNAV), was later isolated from most $H$. cir-

\footnotetext{
* Corresponding author: Yuji Tomaru; E-mail, tomaruy@affrc.go.jp

${ }^{\dagger}$ Present address: Faculty of Agriculture, Kochi University, Otsu-200, Monobe, Nankoku, Kochi 783-8502, Japan

${ }^{\ddagger}$ Present address: Department of Marine Bioscience, Fukui Prefectural University, 1-1 Gakuen-cho, Obama, Fukui 917-0003, Japan
}

cularisquama bloom waters in western Japan (Tomaru et al. 2004). Simultaneous occurrence of $H$. circularisquama blooms and viruses (including unidentified species) in western Japan have been observed almost every year since 2001; and most of the viruses were recognized as HcRNAV using molecular biological methods (Tomaru et al. 2007). Therefore, HcRNAV infection is considered to be one of the most significant factors affecting the population dynamics of $H$. circularisquama (Nagasaki et al. 2004, Tomaru et al. 2007). On the other hand, the ecological relationship between $H$. circularisquama blooms and $\mathrm{HcV}$ is poorly understood. Using transmission electron microscopy, Tomaru \& Nagasaki (2004) reported the detection of $H$. circularisquama cells harboring $\mathrm{HcV}$-like particles during bloom disintegration in Fukura Bay on the south coast of Awaji Island, Hyogo Prefecture, Japan in 2002; however, HcV isolation from the natural water samples was unsuccessful.

To determine the ecological significance of the viruses in H. circularisquama blooms, further study of their relationships and occurrence using constant monitoring are important. Here we show the co-occurrence of $\mathrm{HcV}$ and HcRNAV in a $H$. circularisquama bloom that occurred in Hiroshima Bay. This supports the idea that two different 
viruses cooperatively affect the $H$. circularisquama bloom dynamics and disintegration. This is the first report of simultaneous isolation and identification of two different viruses both infecting $H$. circularisquama from the same waters.

\section{Materials and Methods}

\section{Sampling}

Water samples from the surface layer $(0 \mathrm{~m})$ and $0.2 \mathrm{~m}$ above the sediment-water interface (B- $0.2 \mathrm{~m})$ were collected at 9:30 a.m. on 19 October 2006 from a semi-enclosed basin in Itsukaichi Fishing Port $\left(34^{\circ} 21.400^{\prime} \mathrm{N}\right.$, $\left.132^{\circ} 21.864^{\prime} \mathrm{E}\right)$ (water depth $=$ ca. $5 \mathrm{~m}$ ) located in northern Hiroshima Bay, Japan (Fig. 1). In this area, heavy blooms of Heterocapsa circularisquama have occurred in 1995, 1997 and 1998 (Matsuyama 2003); since then, no large scale blooms have been reported. Water temperatures of the surface and bottom water samples were respectively $21.4^{\circ} \mathrm{C}$ and $22.4^{\circ} \mathrm{C}$; and the salinities were respectively $28.8 \mathrm{psu}$ and $31.4 \mathrm{psu}$. The dominant phytoplankton was Prorocentrum triestinum Schiller (Dinophyceae) with a cell density of $1.8 \times 10^{3}$ cells $\mathrm{mL}^{-1}$ at $0 \mathrm{~m}$. The abundance of $H$. circularisquama was below the detection limit $\left(<50\right.$ cells $\left.\mathrm{mL}^{-1}\right)$ where we could detect $H$. circularisquama in the surface water samples only after concentration using a $20 \mu \mathrm{m}$ plankton filter.

\section{Algal cultures}

Three clonal strains of $H$. circularisquama, HU9433-P, MZ2 and HCLG-1, which have been previously reported in Tomaru et al. (2004), were used as hosts for virus isolation. Based on HcRNAV susceptibility spectra, $H$. circular-

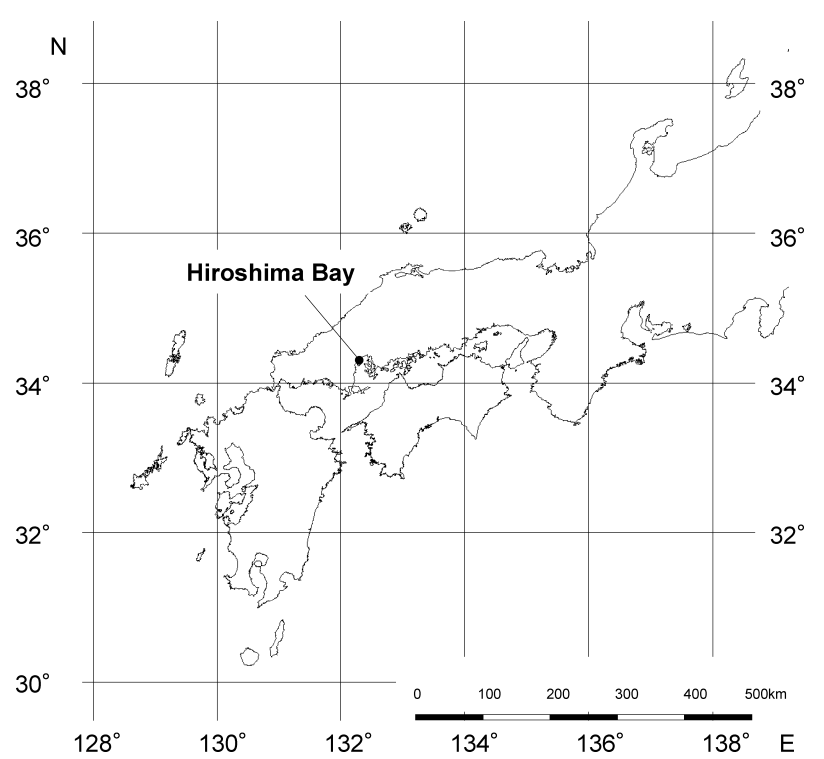

Fig. 1. Map showing the location of Itsukaichi Fishing Port, Hiroshima Bay where seawater samples were collected. isquama strains are roughly divided into two-types: the UAtype and the CY-type, where they exhibit complementary host-type-virus-type specificities, i.e. UA-type H. circularisquama strains infect only UA-type HcRNAV but not the CY-type HcRNAV, and vice versa (Tomaru et al. 2004). The host strains HU9433-P and MZ2 belong to the UAtype $H$. circularisquama, and HCLG-1 belongs to the CYtype. Although the strain MZ2 is susceptible to the UA-type HcRNAV, its virus-induced cell lysis symptoms are faint and delayed (Mizumoto et al. 2008). All of the host strains are susceptible to the 10 strains of $\mathrm{HcV}$ isolated (HcV01HcV10) (Nagasaki et al. 2003).

The $H$. circularisquama strains were grown in modified SWM3 medium (Itoh \& Imai 1987) enriched with $2 \mathrm{nM}$ $\mathrm{Na}_{2} \mathrm{SeO}_{3}$ under a $12 \mathrm{hL}: 12 \mathrm{hD}$ cycle with 130 to $150 \mu \mathrm{mol}$ photons $\mathrm{m}^{-2} \mathrm{~s}^{-1}$ using cool white fluorescent illumination at $20^{\circ} \mathrm{C}$.

\section{Isolation of viruses}

The water samples were filtered through $0.8 \mu \mathrm{m}$ membrane filters (Nuclepore) to remove eukaryotic microorganisms and most bacteria. Aliquots $(1.0 \mathrm{~mL})$ of the filtrates obtained from water samples were inoculated into exponentially growing $H$. circularisquama cultures $(1.0 \mathrm{~mL})$ before being incubated. Algal cultures inoculated with SWM3 served as controls. We cloned the viruses using two cycles with the extinction dilution procedure (Suttle 1993, Tomaru et al. 2004) from lysed cultures of $H$. circularisquama. The cloned pathogens were made free of bacterial contamination by filtration through a $0.2 \mu \mathrm{m}$ Dismic-25cs filter (Advantec Co. Ltd.); and then transferred to another exponentially growing host culture. The resultant lysate was regarded as a clonal virus suspension; and used for further experiments.

\section{TEM}

Transmission electron microscopy (TEM) was performed according to the method described by Tomaru et al. (2004). Vigorously growing cultures of $H$. circularisquama were inoculated with a viral suspension at a concentration of $5 \%$ (v/v). H. circularisquama cultures inoculated with SWM-3 medium served as the control. An aliquot of cell suspension was sampled at $30 \mathrm{~h}$ post-inoculation (pi) and processed for TEM observation (Tomaru et al. 2004). Thin sections of the cells were stained with $4 \%$ uranyl acetate and 3\% lead citrate; and observed at $80 \mathrm{kV}$ using a JEOL JEM-1010 transmission electron microscope. The viruses alone were negatively stained with $4 \%$ uranyl acetate and observed using TEM. Particle diameters were estimated using the negatively stained images.

\section{Analysis of the virus genome}

The virus particles of $\mathrm{HcV}$ and HcRNAV strains established in this study were collected according to the method 
described by Tomaru et al. (2004). The genome size of $\mathrm{HcV}$ was estimated using pulsed-field gel electrophoresis (PFGE); and partial genome sequencing of HcRNAV and $\mathrm{HcV}$ were conducted according to the methods described by Nagasaki et al. (2005a) and Nagasaki et al. (2005b), respectively.

\section{Infection specificities of viruses}

To examine the intraspecies host specificity of the virus strains isolated in the present study, viral suspension was inoculated $(\mathrm{v} / \mathrm{v}=5 \%)$ independently into exponentially growing cultures of the three $H$. circularisquama strains (HU9433-P, MZ2 and HCLG-1). The culture plates were incubated under the same conditions of light and temperature as shown above, and the occurrence of algal lysis was monitored by optical microscopy. For comparison, growth of host cultures, not having undergone viral inoculation, were also monitored. Algal cultures in which the majority of cells lost mobility and were degraded were scored as lytic due to the inoculum.

\section{Results and Discussion}

\section{Virus identification}

We isolated viruses infectious to Heterocapsa circularisquama from water samples of the surface and bottom layers.

Two large dsDNA viruses, virus strains HcV-ITD01 and HcV-ITD02, were isolated only from surface waters using H. circularisquama strain HU9433-P and MZ2 as hosts, respectively. TEM observations showed the sizes of the viruses were $183-210 \mathrm{~nm}$ and $183-191 \mathrm{~nm}$, respectively (Fig. 2A, B); and the daughter virus particles accumulated in the host cytoplasm at $30 \mathrm{~h}$ pi (Fig. 3A-D). The morphological and physiological characteristics of these isolates were similar to $\mathrm{HcV}$ (Tarutani et al. 2001, Nagasaki et al. 2003). PFGE analysis showed the genome sizes of these dsDNA viruses were comparable to that of $\mathrm{HcV}$, ca. 388 kbp (Fig. 4) (Nagasaki et al. 2005b), and the partial genome sequences of these viruses ( $591 \mathrm{bp}$ ) were completely identical to the putative major capsid protein region of $\mathrm{HcV}$ (HcV03) (Table 1). In comparison, for plant viruses, they are considered to be the same virus species if the similarity in the amino acid sequences for the virus coat protein region is at $>90 \%$ (Shukla et al. 1994). Integrating the physiology, morphology and genomic features, we concluded that both the large dsDNA viruses that were isolated in this study were $\mathrm{HcV}$.

However, PFGE analysis showed a difference in genome structure between the large dsDNA virus HcV-ITD02 and the previously described $\mathrm{HcV}$. Nucleic acid extracted from HcV-ITD01 exhibited a single band $388 \mathrm{kbp}$ in length that is similar to previously reported $\mathrm{HcV}$ (388 kbp; Nagasaki et al. 2005b). Contrastingly, HcV-ITD02 genomic DNA showed two bands differing in size at 388 and $350 \mathrm{kbp}$ (Fig.
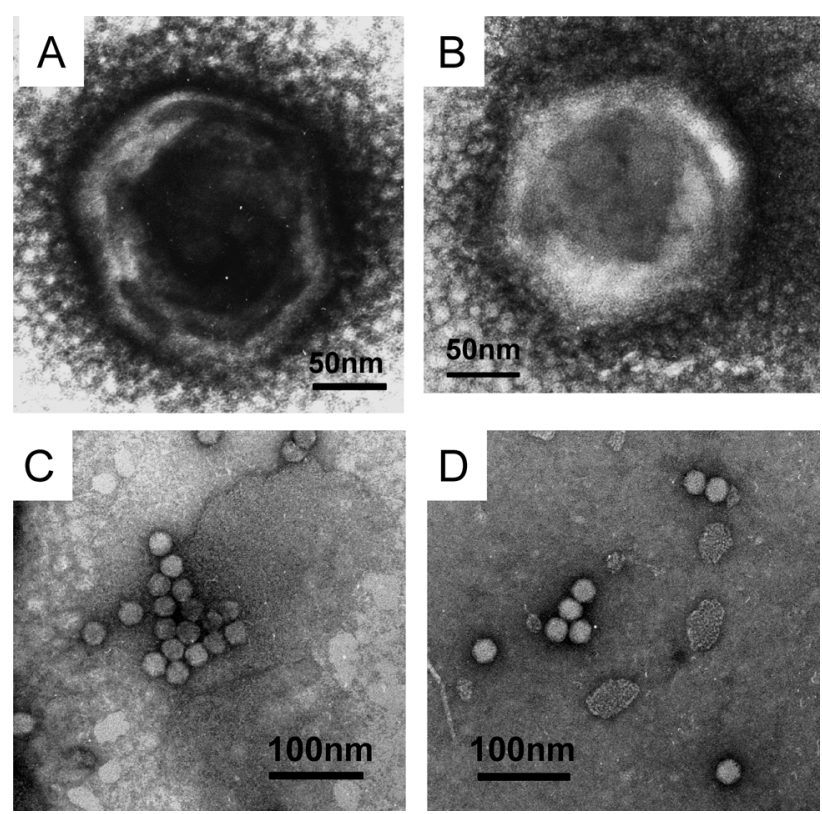

Fig. 2. Transmission electron micrographs of negatively stained particles of HcV-ITD01 (A), HcV-ITD02 (B), HcRNAV-ITR01 (C) and HcRNAV-ITR02 (D) in the culture lysate.

4). Similarly, the circular genomic DNA of Ectocarpus siliculosus (Dillwyn) Lyngbye (Phaeophyceae) virus shows two prominent bands in PFGE gels corresponding to an intact circular DNA and a linear DNA where the latter had been generated presumably by artificial breakage (Lanka et al. 1993). Our PFGE analysis suggested the possibility that the $\mathrm{HcV}$ genome may be circular DNA. Further studies are essential to characterize the genome structure of this virus.

The small ssRNA viruses, virus strains HcRNAV-ITR01 and -ITR02, were isolated using H. circularisquama strain HCLG-1 as the host from both surface and bottom water samples, respectively. TEM observations showed the sizes of these viruses were $27-29 \mathrm{~nm}$ and $27-32 \mathrm{~nm}$, respectively (Fig. 2C, D); and for both, the daughter virus particles accumulated in the host cytoplasm at $30 \mathrm{~h}$ pi (Fig. 3E-H). The accumulation patterns of these viruses in the host cell, random aggregations and crystalline array formations, were similar to HcRNAV (Tomaru et al. 2004). The partial genome sequence analyses revealed $97.6 \%$ of the partial nucleotide sequence and $>96 \%$ of the amino acid sequence in the ORF-2 (capsid protein gene) of HcRNAV-ITR01 and -ITR02 coincided with the CY-type HcRNAV (HcRNAV109) (Table 1). From the above data, both RNA viruses isolated in this study were concluded to be HcRNAV.

\section{Infection specificities of viruses}

Both $\mathrm{HcV}$ strains caused lysis in all three $H$. circularisquama strains tested; whereas in contrast, the two HcRNAV strains were lytic in only one $H$. cirucularisquama strain, HCLG-1 (Table 2). This is similar to our previous 

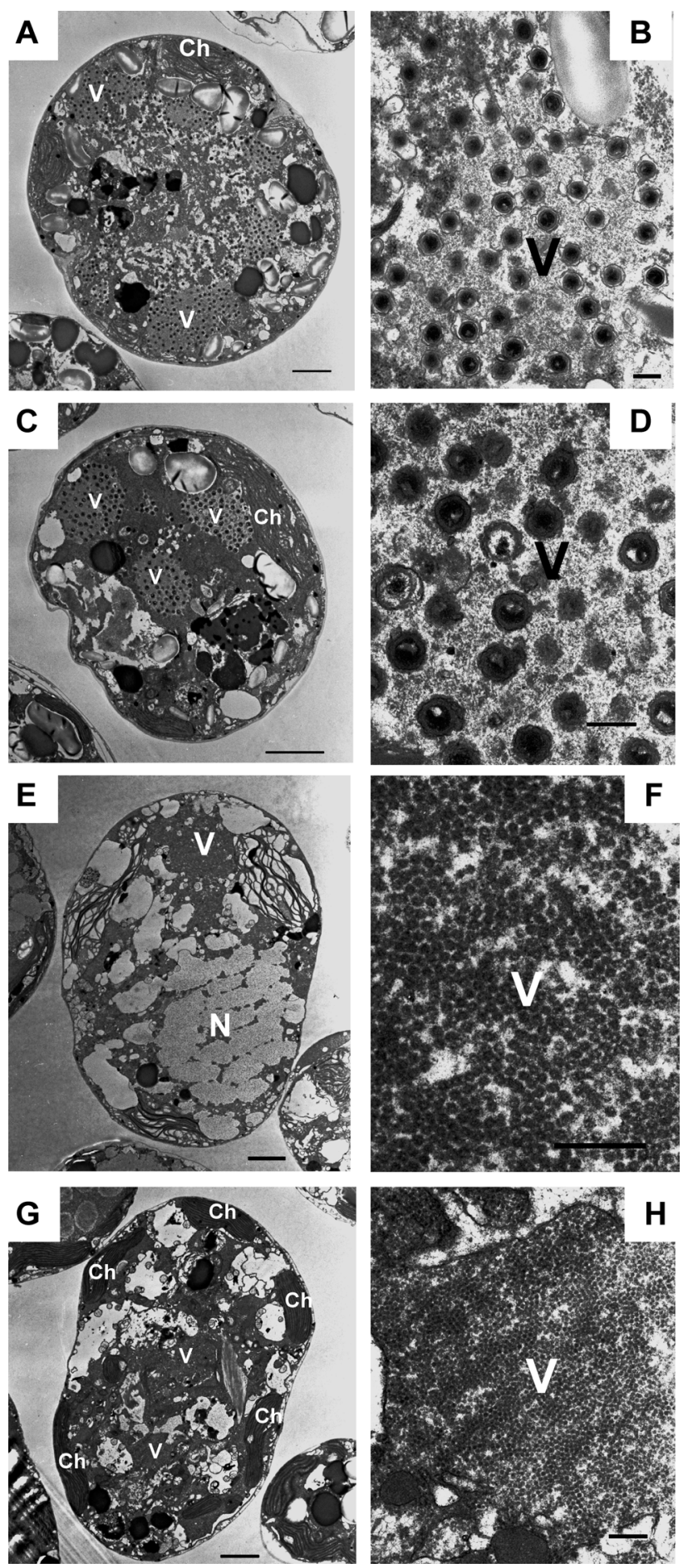

Fig. 3. Transmission electron micrographs of ultra thin sections of Heterocapsa circularisquama. A, C, E and G: cells infected with viruses at $30 \mathrm{~h}$ post-infection. $\mathrm{B}, \mathrm{D}, \mathrm{F}$ and $\mathrm{H}$ : higher magnification of the virus-like particles of A, C, E and G, respectively. A, B: host strain HU9433-P infected with HcV-ITD01; C, D: host strain MZ2 infected with HcV-ITD02; E, F: host strain HCLG-1 infected with HcRNAV-ITR01; and G, H: host strain HCLG-1 infected with HcRNAV-ITR02. Scale bars indicate $2 \mu \mathrm{m}$ in A, C, E and G; and $200 \mathrm{~nm}$ in B, D, F and H. Ch: chloroplast; N: nucleus; $\mathrm{V}$ : virus-like particles.

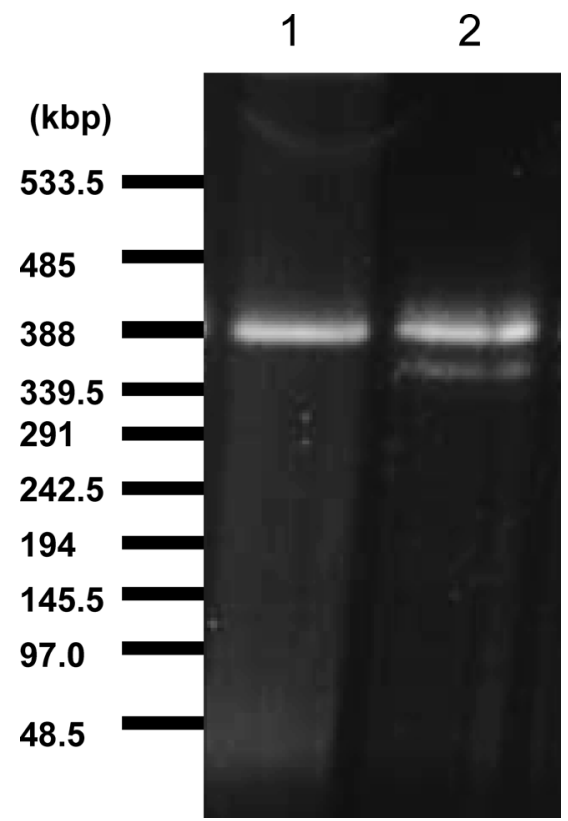

Fig. 4. Genome size of viruses as determined by pulsed-field gel electrophoresis. A single band $(388 \mathrm{kbp})$ and two bands differing in size (388 and $350 \mathrm{kbp}$ ) are observed in lane 1 and lane 2, respectively. Lane 1, HcV-ITD01; lane 2, HcV-ITD02.

Table 1. Percentage of identical nucleotides and amino acids in isolated virus strains as compared to $\mathrm{HcV}$ or HcRNAV.

\begin{tabular}{lcc}
\hline & \multicolumn{2}{c}{ Nucleotides/amino acids (\%) } \\
\cline { 2 - 3 } Virus strains & $\begin{array}{c}\text { 591 nt in a putative } \\
\text { major capsid protein } \\
\text { of HcV03 }\end{array}$ & $\begin{array}{c}\text { 678 nt in a capsid } \\
\text { protein of } \\
\text { HcRNAV109 }\end{array}$ \\
\hline HcV-ITD01 & $100 / 100$ & - \\
HcV-ITD02 & $100 / 100$ & - \\
HcRNAV-ITR01 & - & $97.6 / 96.9$ \\
HcRNAV-ITR02 & - & $97.6 / 97.3$ \\
\hline
\end{tabular}

results concerning strain-specificity of $\mathrm{HcV}$, which is considered much lower than HcRNAV (Nagasaki et al. 2003, Tomaru et al. 2004). Our previous studies showed H. circularisquama strains HU9433-P and MZ2 belong to the UAtype and HCLG-1 belongs to the CY-type (Mizumoto et al. 2008, Tomaru et al. 2004) (see Materials and Methods). Thus, the small viruses HcRNAV-ITR01 and -ITR02 isolated in the present survey were considered to be members of the CY-type HcRNAVs.

\section{Implications}

Here we found the $\mathrm{HcV}$ strains were only able to be isolated using the UA-type host, HU9433-P and MZ2, but not with the CY-type host, HCLG-1. Based on the results of the infection specificity tests (Table 2), $\mathrm{HcV}$ could potentially be isolated using the host strain HCLG-1, but the actual re- 
Table 2. Infection specificities of viruses to Heterocapsa circularisquama strains.

\begin{tabular}{|c|c|c|c|c|}
\hline \multirow{2}{*}{$\begin{array}{l}\text { H. circularisquama } \\
\text { strain }\end{array}$} & \multicolumn{4}{|c|}{ Virus strain } \\
\hline & HcV-ITD01 & HcV-ITD02 & HcRNAV-ITR01 & HcRNAV-ITR02 \\
\hline HU9433-P & + & + & - & - \\
\hline MZ2 & + & + & - & - \\
\hline HCLG-1 & + & + & + & + \\
\hline
\end{tabular}

+ , algal lysis; -, no effect.

sult differed. In many cases, both the UA-type and CY-type HcRNAV are simultaneously isolated from natural waters (Tomaru et al. 2004), however, in the present study the CYtype HcRNAV strains were successfully isolated but no UA-type HcRNAV strain was. In order to interpret these results, the relationship between the host-strain specificity of infectious viruses and their viral abundances should be considered. The most plausible explanation for this phenomenon may be that the abundance of CY-type HcRNAV was much higher than $\mathrm{HcV}$; thus only CY-type HcRNAV was isolated using the extinction dilution method where the most abundant viruses tend to be isolated. $\mathrm{HcV}$, having a wide host range, may only have been isolated using UAtype hosts because the most abundant virus causing lysis of UA-type hosts was not UA-type HcRNAV but HcV. For further understanding of this host-virus ecological relationship, the development of a quantitative detection method for viral abundance will be essential at the species or type level.

The water of the Itsukaichi Fishing Port one week prior to sampling was discolored due to an algal bloom (data not shown); however, on the day of sampling the water was clear. Therefore, the red-tide bloom at this port may have collapsed during the 7 days prior to the sampling. We detected $H$. circularisquama cells at considerably lower concentrations from the water samples on the sampling day (see Materials and Methods). In our previous surveys, $H$. circularisquama blooms were accompanied by the occurrence of viruses lytic to $H$. circularisquama (Nagasaki et al. 2004, Tomaru et al. 2007). From the above results, the viruses isolated in this study were considered to be $\mathrm{HcV}$ and HcRNAV; and were propagated during the process of a H. circularisquama bloom that occurred just before our sampling in October 2006. This suggests two distinct virus species may have cooperatively affected the disintegration of the $H$. circularisquama bloom.

In Ago Bay, central Japan, where $H$. circularisquama blooms occur almost every year, where we have annually detected and isolated HcRNAV since 2001. In contrast, $\mathrm{HcV}$ has not been detected or isolated from this location (Nagasaki et al. 2004, Tomaru et al. 2007). HcRNAV has been isolated from a wide region of the western Japanese coast from central Japan to Kyushu Island (Tomaru et al. 2004). The first detection and isolation of $\mathrm{HcV}$ was from
Tanabe Bay on the east side of the Kii-Chanel in 1999 (Tarutani et al. 2001) although HcRNAV was not detected from the water samples. Our previous study showed that $H$. circularisquama cells intracellularly harboring HcV-like particles and cells harboring HcRNAV-like particles coexisted in a host bloom occurring in Fukura Bay on the south coast of Awaji Island in the Seto Inland Sea, 2002 (Tomaru \& Nagasaki 2004). Integrating the previous observations and our present results (successful isolation of $\mathrm{HcV}$ and HcRNAV from the same waters), these viral infections are considered to be important factors functioning in the termination of $H$. circularisquama blooms. It is difficult to evaluate the contribution of each virus type in determining the outcome of the bloom dynamics. Possibly the two distinct virus species affect the dynamics of $H$. circularisquama blooms in natural water environments and are a significant factor determining the fate of blooms. To understand the interaction between $H$. circularisquama blooms and virus infections more precisely, further field surveys as well as physiological studies examining relationships with environmental factors should be performed.

\section{Acknowledgements}

We are grateful to Y. Shirai for her technical support and I. Imai (Hokkaido University, Japan) for providing the Heterocapsa circularisquama HU9433-P culture. This work was partially supported by a grant-in-aid for scientific research (A)(2) (no. 20247002) from the Ministry of Education, Science, Sports, and Culture of Japan.

\section{References}

Horiguchi T (1995) Heterocapsa circularisquama sp. nov. (Peridiniales, Dinophyceae): a new marine dinoflagellate causing mass mortality of bivalves in Japan. Phycol Res 43: 129-136.

Itoh K, Imai I (1987) Rafido so (Raphidophyceae). In: A Guide for Studies of Red Tide Organisms (ed Japan Fisheries Resource Conservation Association). Shuwa, Tokyo, pp. 122-130. (in Japanese)

Lanka STJ, Klein M, Ramsperger U, Müller DG, Knippers R (1993) Genome structure of a virus infecting the marine brown alga Ectocarpus siliculosus. Virology 193: 802-811.

Matsuyama Y (2003) Physiological and ecological studies on 
harmful dinoflagellate Heterocapsa circularisquama-I. Elucidation of environmental factors underlying the occurrence and development of $H$. circularisquama red tide. Bull Fish Res Agency 7: 24-105. (in Japanese with English abstract)

Mizumoto H, Tomaru Y, Takao Y, Shirai Y, Nagasaki K (2008) Diverse responses of the bivalve-killing dinoflagellate Heterocapsa circularisquama to infection by a single-stranded RNA virus. Appl Environ Microbiol 74: 3105-3111.

Nagasaki K, Shirai Y, Takao Y, Mizumoto H, Nishida K, Tomaru Y (2005a) Comparison of genome sequences of single-stranded RNA virus infecting the bivalve-killing dinoflagellate Heterocapsa circularisquama. Appl Environ Microbiol 71: 88888894.

Nagasaki K, Shirai Y, Tomaru Y, Nishida K, Pietrokovski S (2005b) Algal viruses with distinct intraspecies host specificities include identical intein elements. Appl Environ Microbiol 71: 3599-3607.

Nagasaki K, Tomaru Y, Nakanishi K, Katanozaka N, Yamaguchi M (2004) Dynamics of Heterocapsa circularisquama (Dinophyceae) and its viruses in Ago Bay, Japan. Aquat Microb Ecol 34: 219-226.

Nagasaki K, Tomaru Y, Tarutani K, Katanozaka N, Yamanaka S, Tanabe H, Yamaguchi M (2003) Growth characteristics and intraspecies host specificity of a large virus infecting the dinofla- gellate Heterocapsa circularisquama. Appl Environ Microbiol 69: 2580-2586.

Shukla DD, Ward CW, Brunt AA (1994) The potyviridae, CAB/International, Oxon, UK, 516 pp.

Suttle CA (1993) Enumeration and isolation of viruses. In: Handbook of methods in aquatic microbial ecology (eds Kemp PF, Sherr E, Cole JJ). Lewis Publishers, Boca Raton, pp. 121-137.

Tarutani K, Nagasaki K, Itakura S, Yamaguchi M (2001) Isolation of a virus infecting the novel shellfish-killing dinoflagellate Heterocapsa circularisquama. Aquat Microb Ecol 23: 103-111.

Tomaru Y, Hata N, Masuda T, Tsuji M, Igata K, Masuda Y, Yamatogi T, Sakaguchi M, Nagasaki K (2007) Ecological dynamics of the bivalve-killing dinoflagellate Heterocapsa circularisquama and its infectious viruses in different locations of western Japan. Environ Microbiol 9: 1376-1383.

Tomaru Y, Katanozaka N, Nishida K, Shirai Y, Tarutani K, Yamaguchi M, Nagasaki K (2004) Isolation and characterization of two distinct types of HcRNAV, a single-stranded RNA virus infecting the bivalve-killing microalga Heterocapsa circularisquama. Aquat Microb Ecol 34: 207-218.

Tomaru Y, Nagasaki K (2004) Widespread occurrence of viruses lytic to the bivalve-killing dinoflagellate Heterocapsa circularisquama along the western coast of Japan. Plankton Biol Ecol 51: 1-6. 